\title{
Allelochemicals as Growth Stimulators for Drought Stressed Maize
}

\author{
Nazimah Maqbool'1, Rumana Sadiq ${ }^{2}$ \\ ${ }^{1}$ Department of Botany, University of Agriculture, Faisalabad, Pakistan \\ ${ }^{2}$ Department of Botany, Government College Women University, Faisalabad, Pakistan \\ Email: nazimahmaqbool@gmail.com
}

How to cite this paper: Maqbool, N. and Sadiq, R. (2017) Allelochemicals as Growth Stimulators for Drought Stressed Maize. American Journal of Plant Sciences, 8, 985997.

https://doi.org/10.4236/ajps.2017.85065

Received: March 9, 2017

Accepted: April 14, 2017

Published: April 17, 2017

Copyright (c) 2017 by authors and Scientific Research Publishing Inc. This work is licensed under the Creative Commons Attribution International License (CC BY 4.0).

http://creativecommons.org/licenses/by/4.0/

Open Access

\begin{abstract}
Sorgaab, an aqueous extract of sorghum leaves was applied to probe the modulation in growth and physiological attributes of maize under drought in lab and greenhouse studies. Sorgaab soaked seeds (10 dilutions) were germinated to assess drought tolerance at germination and seedling growth stages. More concentrated Sorgaab solutions $\left(2 \mathrm{~mL} \cdot \mathrm{L}^{-1}\right)$ were damaging, while lower concentration in the range of 0.75 to $1.5 \mathrm{~mL} \cdot \mathrm{L}^{-1}$ improved the root and shoot growth of maize under drought. Applied drought stress decreased chlorophyll $\mathrm{b}$ greater than chlorophyll a that improved the $\mathrm{chl} \mathrm{a} / \mathrm{b}$ ratio. Application of Sorgaab also improved the internal $\mathrm{CO}_{2}$ assimilation, which increased the net photosynthesis and $A / E$ ratio of drought affected plants. Soluble phenolics and anthocyanins were also more increased in plant receiving Sorgaab under drought than control. Although greater concentrations of phenolic acids inhibit the uptake of ions, but its lower concentrations stimulate the uptake of $\mathrm{K}^{+}$, $\mathrm{Ca}^{2+}, \mathrm{NO}_{3}, \mathrm{PO}_{4}$. In conclusion, although high concentrations of Sorgaab reduced the growth of plants, it might alleviate the adverse effects of drought, if applied at the low concentration. Dilute concentrations of Sorgaab can be utilized as a natural source for improving drought resistance in maize both at germination and later growth stages.
\end{abstract}

\section{Keywords}

Sorgaab, Stimulator, Low Dilutions, Sorghum Water Extract

\section{Introduction}

Drought is one of the straits which plant has to experience once for the life or the whole life. The survival under dwindling water resources is difficult and plants adopt various strategies to grapple these alterations in the environment. Phenolic acids produced by plants are found to be among those compounds that 
act as osmoprotectants and antioxidants under stresses [1]. Variation in the concentrations of phenolic acids has a pivotal role in plants survival. Recent researches have revealed that external applications of phenolic compounds help plants to cope with these environmental fluctuations [2]. In nature, phenolic acids are part of allelochemicals that are produced by the plants against pathogens and mineral competition among plant species [3]. Nowadays, researches are carried out to find out the concentrations of naturally occurred phenolic acids (allelochemicals) that will prove to be beneficial for plant protection and make their survival possible under drastic conditions. Water extract from sorghum residues has the inhibitory effect on germination and reduced growth of corn (Zea mays L.) and wheat [4]. According to [5], reduction in growth and yield was probably due to phenolic acids which were the characteristic components of sorghum allelopathy.

The allelopathic sorghum has been manipulated for weed suppression in wheat [6]. Sorgaab is an allelopathic plant extract obtained from sorghum. It has been successfully used as foliar spray to eliminate weeds from fields of wheat [7] and soybean [8]. The chemical analysis of Sorgaab has revealed that it contains the high amount of phenolic compounds [9]. Several researchers showed that germination and growth inhibition in crops were due to the allelopathic effect of water extracts of various weeds [10]. Recently, it has been shown that phenolic compounds, among the plants secondary metabolites, are effective in conferring tolerance to abiotic stresses [11] [12]. Various strategies can be adopted to overcome the adverse effects of these environmental factors. Such one approach may be the use of different dilutions of Sorgaab, an allelopathic water extract of sorghum leaves.

Maize (Zea mays L.), a multipurpose crop, is the rich source of proteins, carbohydrates, oils and general human consumption. In Pakistan, average grain yield of maize is very low i.e. $1865 \mathrm{~kg} \cdot \mathrm{ha}^{-1}$ [13], in spite of increasing demand of food and fodder and the better production technology. This decrease is due to the exposure of maize to multiple abiotic stresses at critical growth stages.

The presence of phenolic acids (Sorgaab) and water stress have the synergistic effect on the growth of crops. The earlier studies reported the allelopathic effect of high doses of water extracts on agricultural crops in unstressed conditions. There is no report on combined impact of allelopathy and abiotic stresses on growing plants. Abiotic stress adversely affects the growth and development of crop plants but how it interacts with allelochemicals has not been studied yet.

This experiment was planned to examine the potential of diluted concentrations (foliar application) of Sorgaab (allelopathic water extract of sorghum) as growth regulator on growth and nutrients uptake of maize seedlings under control and drought conditions.

\section{Materials and Methods}

The present study was conducted to determine the responses in Maize (Zea mays L.) to foliar application of diluted concentrations of Sorgaab under water 
deficit conditions. Healthy and apparently viable seeds of cultivar EV-1098 were obtained from Maize and Millets Research Institute (MMRI), Yousafwala, Sahiwal. A pot experiment was conducted in Old Botanical Garden, University of Agriculture, Faisalabad, Pakistan during Spring 2010. Eight concentrations from 0 - $2 \mathrm{~mL} \cdot \mathrm{L}^{-1}$ were diluted from Sorgaab $\left(10 \mathrm{~g} 100 \mathrm{~mL}^{-1}\right)$. The experiment was completely randomized (CRD) with two factors factorial including ten treatments and three replications. Plants of maize were grown up to knee high stage in pots containing $10 \mathrm{~kg}$ of loam soil. The plants were foliar sprayed with water, $0.25,0.50,0.75,1.00,1.25,1.50,1.75$ and $2.00 \mathrm{~mL} \cdot \mathrm{L}^{-1}$ of water with three replicates for each concentration and one set of three replicates were kept unsprayed for both treatments. Then half of the pots were supplied daily with normal irrigation water while other half were given dry down treatment to $50 \%$ of the field capacity of the soil in order to induce water stress. After 15 days of growth under drought condition, the gas exchanges attributes were measured then the plants were harvested and data was recorded in triplicate.

Data was statistically analyzed using CoStat and LSD Test for comparison of means. The graphical presentation was done using MS-Excel.

\section{Results}

\subsection{Effect of Sorgaab Alone}

Effect of allelochemical extract of sorghum studied on the growth attributes as shown in Figure 1. All the dilutions enhanced the shoot length especially at 0.75 $\mathrm{mL} \cdot \mathrm{L}^{-1}$. Root length was supercharged by $1.75 \mathrm{~mL} \cdot \mathrm{L}^{-1}$ and $2.00 \mathrm{~mL} \cdot \mathrm{L}^{-1}$ Sorgaab. Shoot fresh and dry weights of maize increased in ascending order with Sorgaab dilutions. Lower concentrations $0.25 \mathrm{~mL} \cdot \mathrm{L}^{-1}$ to $0.75 \mathrm{~mL} \cdot \mathrm{L}^{-1}$ advanced root fresh and dry biomass due to the production of root hairs as compared to others levels. Less number of roots with more root hairs was marked in case of lower concentrations. Maximum root dry weights at higher are due to greater number of roots with little root hairs. More or less enhanced stem diameter with comparison to unsprayed plants was noted as represented in Figure 1, Sorgaab less than $2.00 \mathrm{~mL} \cdot \mathrm{L}^{-1}$ strength inclined leaf area.

Dilutions of Sorgaab $\left(0.75 \mathrm{~mL} \cdot \mathrm{L}^{-1}-2.00 \mathrm{~mL} \cdot \mathrm{L}^{-1}\right)$ establish significant effect on chl-a contents of maize plants. While, chl-b declined with higher levels of extract. A positive impact was observed on chl-T, however, reduction in chlorophyll a/b ratio occurred as demonstrated in Figure 2. Photosynthetic and transpiration rates were also significantly enhanced as presented in Figure 3. Maximum photosynthetic activity was observed at the level of $0.25 \mathrm{~mL} \cdot \mathrm{L}^{-1}$ and 0.75 $\mathrm{mL} \cdot \mathrm{L}^{-1}$ promoted transpiration rate. Water use efficiency was greater at 0.25 $\mathrm{mL} \cdot \mathrm{L}^{-1}$ to $1.00 \mathrm{~mL} \cdot \mathrm{L}^{-1}$ and decreased at later concentrations. Stomatal conductance improved at $1.25 \mathrm{~mL} \cdot \mathrm{L}^{-1}$ to $1.75 \mathrm{~mL} \cdot \mathrm{L}^{-1}$ Sorgaab dilutions as compared to unsprayed plants, nonetheless, maximum was depicted at $1.25 \mathrm{~mL} \cdot \mathrm{L}^{-1}$. Slight increase was marked in case of substomatal $\mathrm{CO}_{2}$ at each level of extract (Figure 3).

Infliction of variegating levels of Sorgaab on maize plants did not impose drastic impact on the concentration of phenolics, free amino acids, $\mathrm{MDA}, \mathrm{H}_{2} \mathrm{O}_{2}$, 

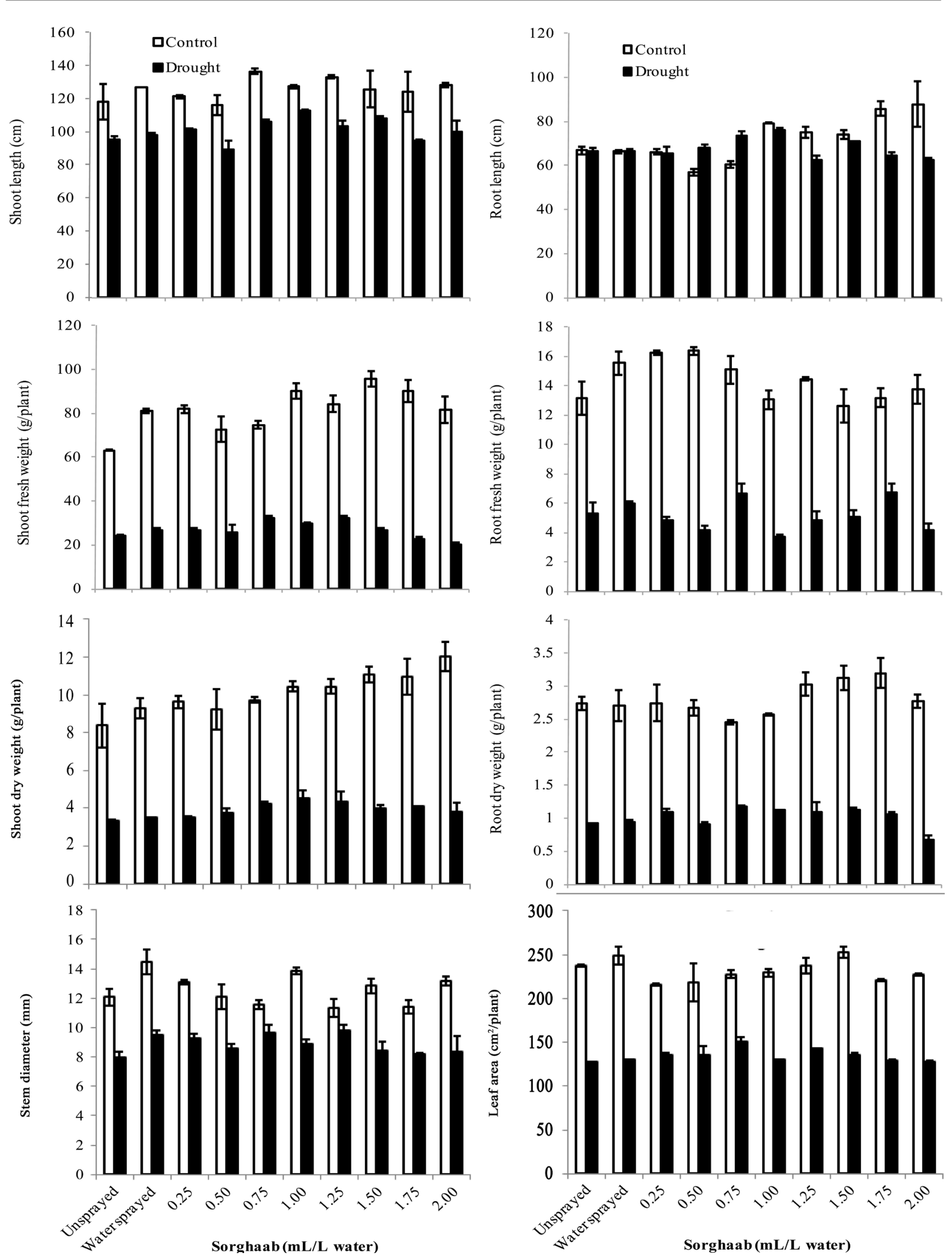

Figure 1. Shoot and root length, shoot and root fresh weights, dry weights, stem diameter and leaf area of maize grown for 15 days under drought and varying levels of Sorgaab. 


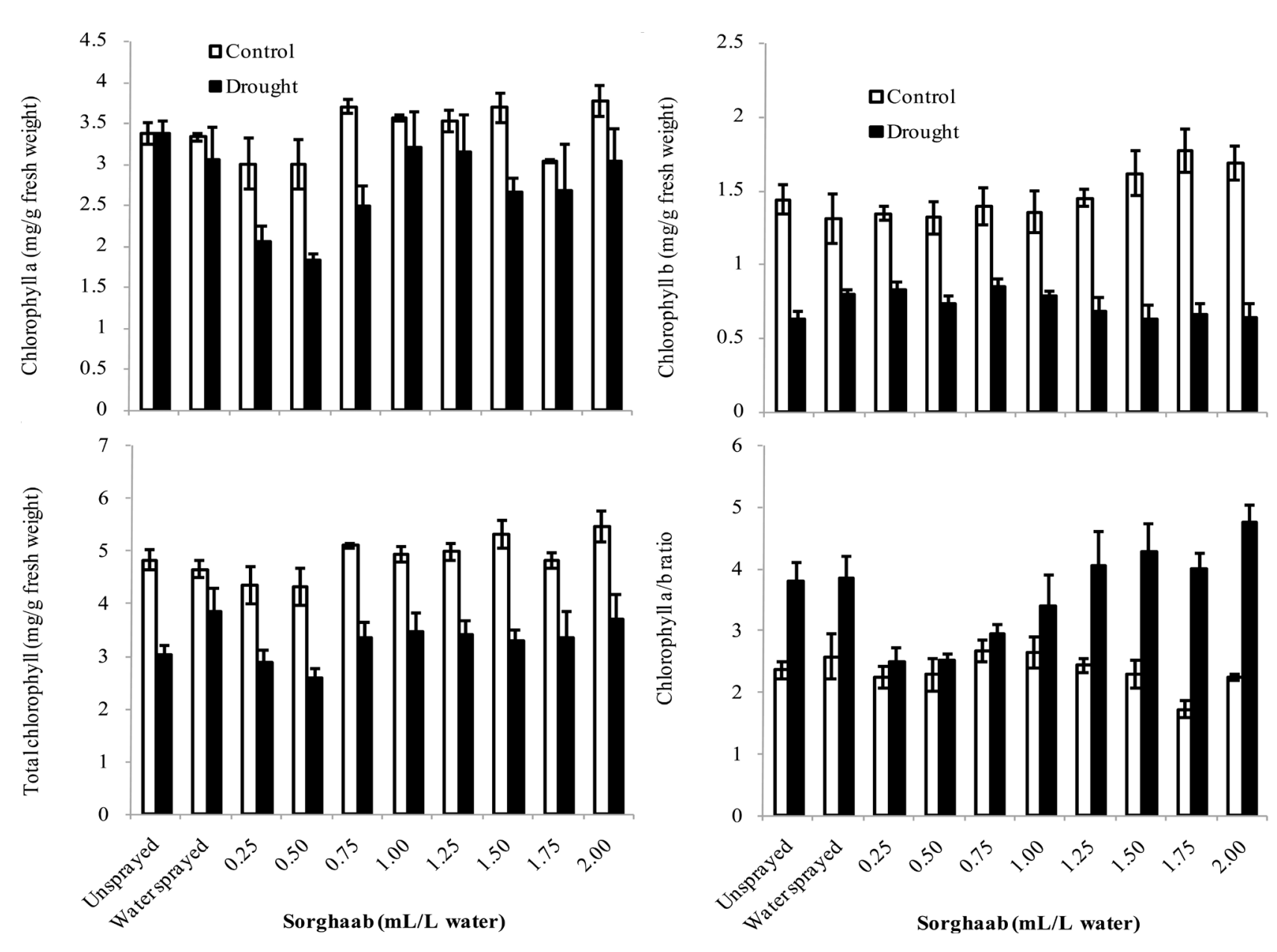

Figure 2. Chlorophyll a, chlorophyll b, Total chlorophyll and Chlorophyll a:b ratio of maize grown for 15 days under drought and varying levels of Sorgaab.

and relative membrane permeability (Figure 4). Anthocyanins swing by foliar spray of $1.00 \mathrm{~mL} \cdot \mathrm{L}^{-1}$ to $1.50 \mathrm{~mL} \cdot \mathrm{L}^{-1}$ dilutions. Uptake of $\mathrm{K}^{+}$by leaf was slightly encouraged by varying dilutions of Sorgaab and similar was noticed in case of roots (Figure 5). The response of root and leaf $\mathrm{Ca}^{2+}$ and $\mathrm{PO}_{4}$ ions to different levels of extract was not significant and elevated response for $\mathrm{NO}_{3}$ contents in leaf and roots was discovered for all foliar sprays with reference to unsprayed plants (Figure 5).

\subsection{Interactive Effect of Sorgaab and Water Stress}

Both the treatments had significant interactive effect on maize growth as represented in Figure 1. Dilutions from $0.75 \mathrm{~mL} \cdot \mathrm{L}^{-1}$ to $1.50 \mathrm{~mL} \cdot \mathrm{L}^{-1}$ showed maximum root and shoot length under drought. Water deficit conditions reduced fresh and dry biomass of shoot and root in presence of foliar sprayed Sorgaab with comparison to control. Slightly higher fresh and dry biomass was measured at $1.00 \mathrm{~mL} \cdot \mathrm{L}^{-1}$ extract along with stress. Extract of $0.75 \mathrm{~mL} \cdot \mathrm{L}^{-1}$ strength in the tenuous absence of water increased stem diameter as well as leaf area (Figure 1).

Photosynthetic pigments were influenced significantly by both applications (Figure 2). Maximal reduction of chl-a was noticed for all the dilutions except 
$1.00 \mathrm{~mL} \cdot \mathrm{L}^{-1}$ and $1.25 \mathrm{~mL} \cdot \mathrm{L}^{-1}$ in the presence of water deficiency. Lower concentrations of extract had increased chl-b as compared to unsprayed plants and fall down with increased levels of Sorgaab. Total chlorophyll and $a / b$ ratio were greater at higher solutions of Sorgaab i.e. $1.00 \mathrm{~mL} \cdot \mathrm{L}^{-1}$ to $2.00 \mathrm{~mL} \cdot \mathrm{L}^{-1}$ (Figure 2). Higher transpiration and photosynthetic rates from $0.75 \mathrm{~mL} \cdot \mathrm{L}^{-1}$ to $1.50 \mathrm{~mL} \cdot \mathrm{L}^{-1}$ sprayed levels under drought was marked as represented in Figure 3. Slight reduction in water use efficiency and elevation in substomatal $\mathrm{CO}_{2}$ at lower levels of extract occurred. Stomatal conductance was boosted at $1.50 \mathrm{~mL} \cdot \mathrm{L}^{-1}$ Sorgaab under water deficit conditions Figure 3.

Anthocyanins and phenolics were markedly increased at highest dilutions of Sorgaab and stress together as presented in Figure 4. Drought produced little MDA with lower concentrations of extract than higher ones and unsprayed
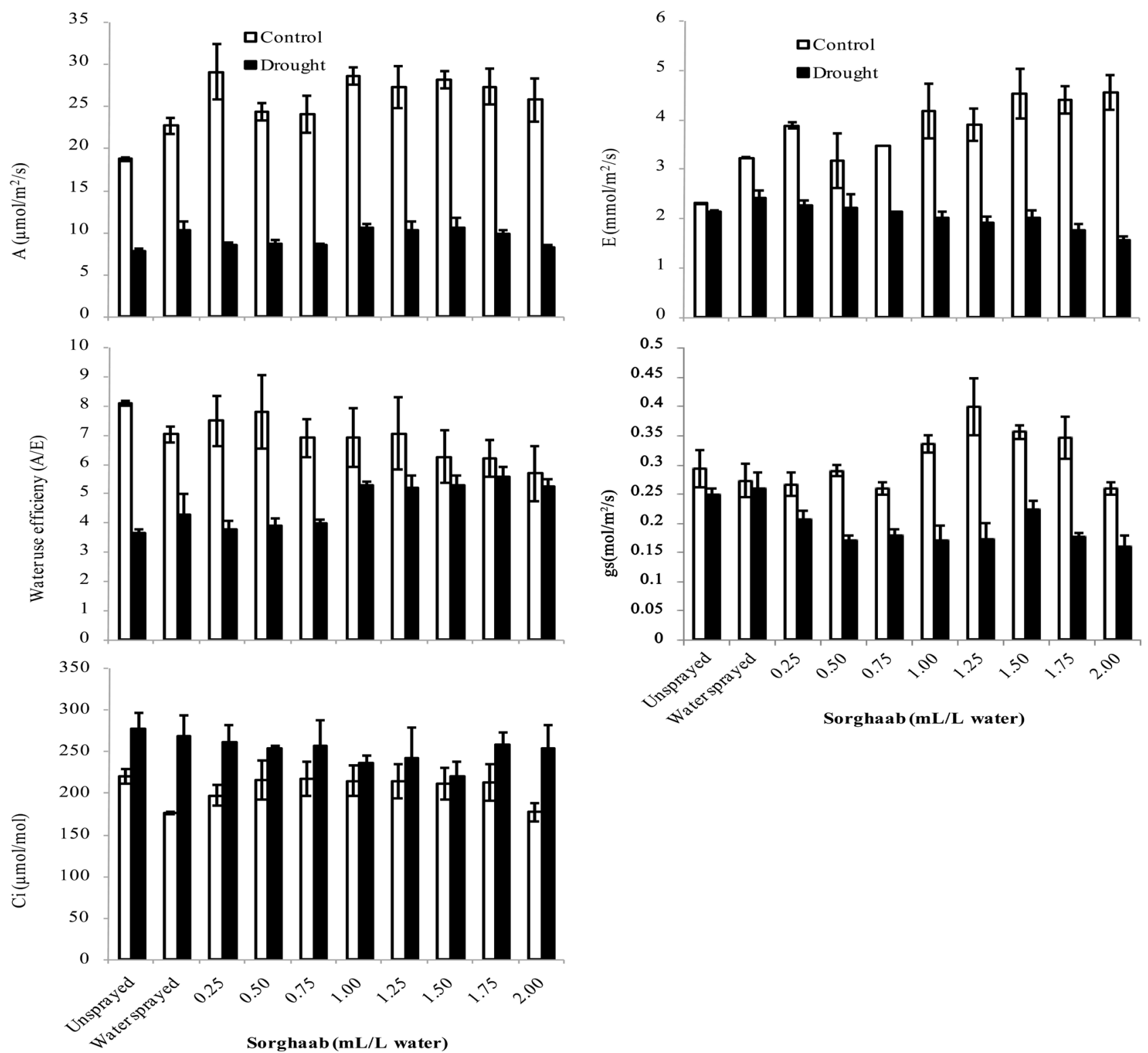

Figure 3. Photosynthetic rate $(A)$, Transpiration rate $(E)$, water use efficiency $(A / E)$, stomatal conductance (gs) and substomatal $\mathrm{CO}_{2}(\mathrm{Ci})$ of maize grown for 15 days under drought and varying levels of Sorgaab. 
plants (Figure 4). Higher percentage for relative membrane permeability was scored for all levels along with stress. Reduced $\mathrm{H}_{2} \mathrm{O}_{2}$ and increased free amino acids were detected than unsprayed ones as demonstrated in Figure 4.

Ionic contents of maize were determined as $\mathrm{Ca}, \mathrm{K}, \mathrm{PO}_{4}$ and $\mathrm{NO}_{3}$ in roots and leaf as represented in Figure 5. Water deficiency and ascending levels of Sorgaab significantly increased shoot and roots $\mathrm{Ca}^{2+}, \mathrm{K}^{+}$ions but lowered for $2.00 \mathrm{~mL} \cdot \mathrm{L}^{-1}$ extract and similar response for $\mathrm{NO}_{3}$ in roots and shoots was discovered. An additive effect of both treatments was observed in case of $\mathrm{PO}_{4}$ contents in vegetative and underground parts of maize (Figure 5).
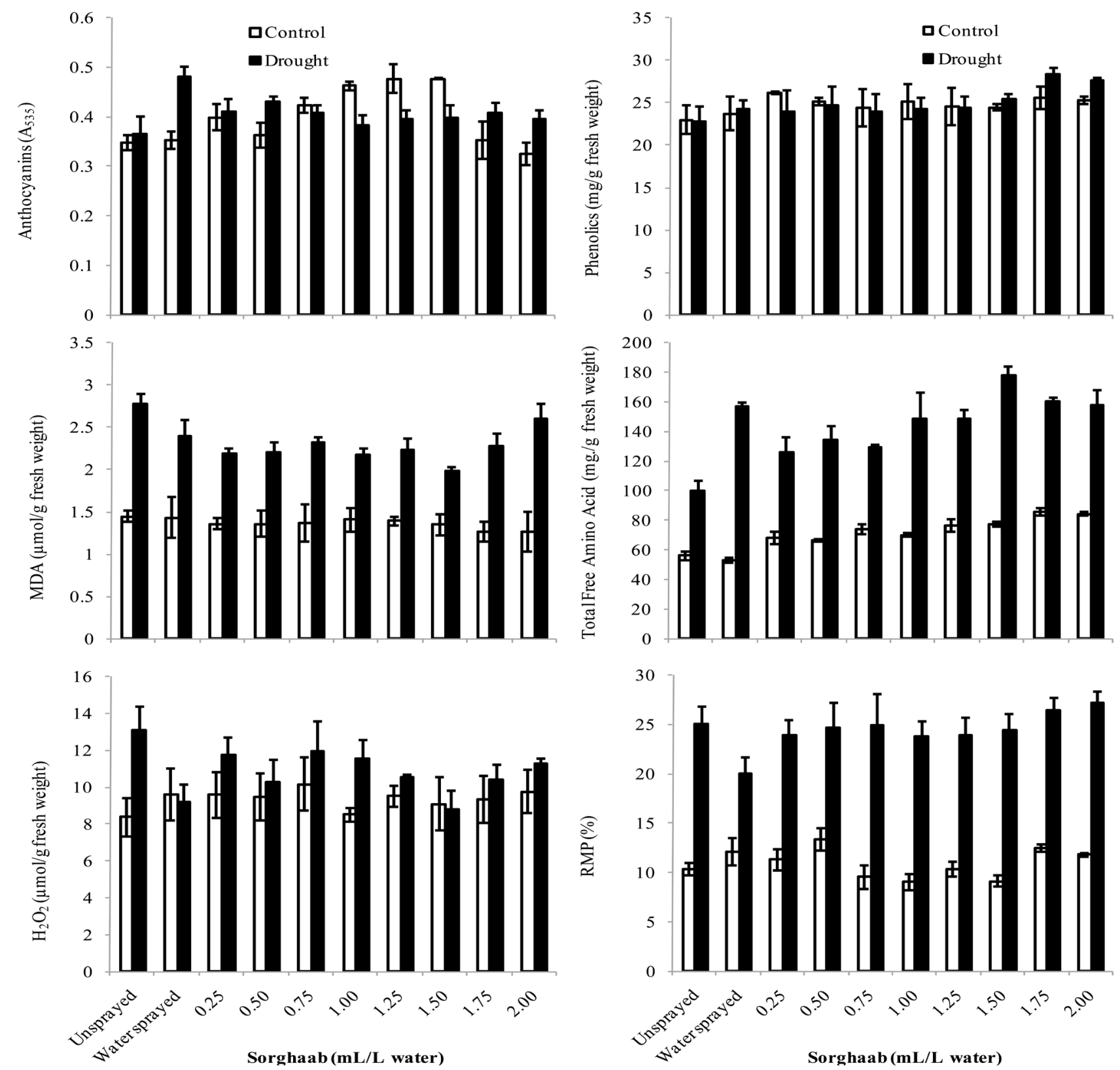

Figure 4. Anthocyanins, Phenolics, MDA, Total free amino acids, $\mathrm{H}_{2} \mathrm{O}_{2}$ and Relative membrane permeability of stressed maize grown for 15 days under varying levels of Sorgaab. 

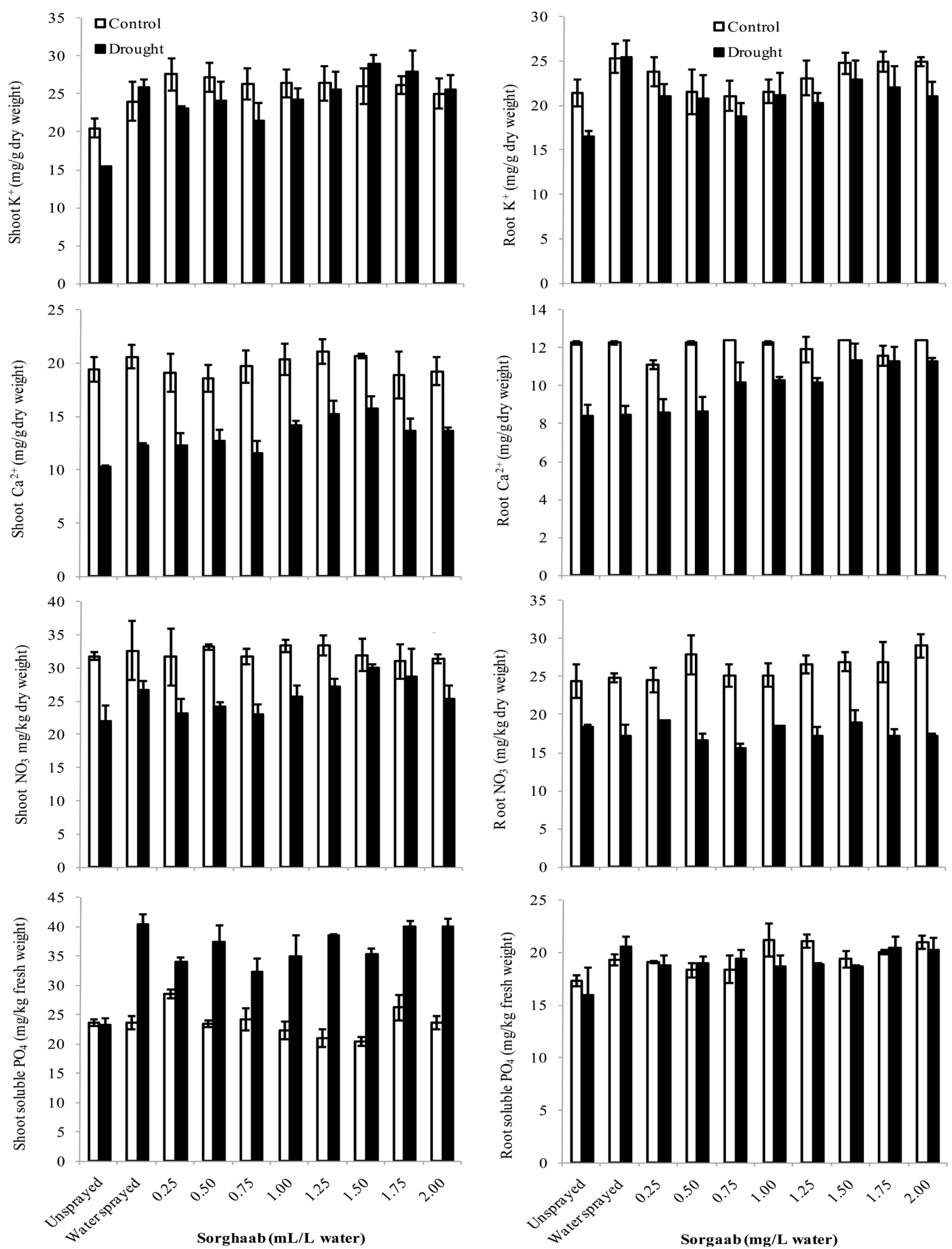

Figure 5. Inorganic nutrients including $\mathrm{K}^{+}, \mathrm{Ca}^{2+}, \mathrm{NO}_{3}$ and $\mathrm{PO}_{4}$ of roots and shoots of maize grown for 15 days under varying levels of Sorgaab. 


\section{Discussion}

Drought is perhaps the most threatening factor in crop production all over the world. In the event of water scarcity, the physiological functions of plants are seriously affected, and in certain cases plant death is the consequence [14]. Drought tolerance in plants is a cost-intensive phenomenon and taxes a substantial share of plant resources [14]. Studies have been conducted to improve drought tolerance in plants by employing a number of ways and means, the most effective and relatively inexpensive is the exogenous application of various chemicals either as seed treatments or foliar spray.

Allelochemical have been widely used to suppress the growth of weeds of noxious plants growing in the crop fields [15] [16] [17], but their exogenous use in promoting plant growth has been rarely investigated. The alleochemicals are secondary compounds synthesized by the plants and most of those are phenolic in nature [3] [10] [18]. In the recent years, the use of plant secondary products (mainly phenolics) has been shown to be associated with the abiotic stress tolerance in various plants [11] [12] [19]. Keeping in view the chemical nature of alleochemicals, their foliar spray was carried out to look for possible role of Sorgaab, (sorghum leaf water extract) used to control weeds in the crop fields, on maize under drought stress.

The determinations made for the growth attributes revealed that under control condition, the foliar application of various aqueous dilutions of Sorgaab was effective on control as well as on the drought stressed maize plants.

It was noted that out of a range of foliar applied Sorgaab dilutions, 1.00 to 1.75 $\mathrm{mL} \cdot \mathrm{L}^{-1}$ were highly effective in improving the shoot and root length, their fresh and dry weight, stem diameter, internodal length, number and area of leaves per plant. [20] reported that allelochemicals from velvetbean (Mucuna pruriens) were effective in improving the growth of rice and corn-kidney when intercropped. The improvements noted in the growth attributes of maize indicated that foliar application of Sorgaab has the potential to bring some profound physiological changes in the leaves, which enabled the maize to withstand under moderate to high drought spell. The basis of improvements in the maize growth characteristics were explored in terms of changes in the photosynthetic pigments and gas exchange characteristics, oxidative damage and some biochemical parameters and nutritional relationships in leaves of drought stressed maize.

Optimum operation of both light and dark reactions of photosynthesis is important for optimal plant growth [21], and drought stress severely impairs these phenomena [22]. The results of the present study indicated that foliar application of Sorgaab dilution was greatly effective in enhancing the contents of both the chlorophyll species and 0.5 to $1.5 \mathrm{~mL} / \mathrm{L}$ dilution of Sorgaab were the most effective in increasing their levels under drought stress. It has been observed that a content of chlorophyll b was greatly damaged as compared to chlorophyll a and their concentration decreased with increased concentration of Sorgaab. The reduced chlorophyll content by allelochemicals (specifically phenolic acids) was thought to be caused by enhanced chlorophyll degradation by enzyme chloro- 
phyllase [23].

The maintenance of photosynthetic machinery functionally is of major importance for drought tolerance. The rapid closure of stomata under stress stops loss of water [24], $\mathrm{CO}_{2}$ diffusion into leaf is restricted resulting in loss of net photosynthetic rate [25]. The effect of Sorgaab dilution on stressed plants showed that net photosynthetic rate, transpiration rate, water use efficiency, substomatal $\mathrm{CO}_{2}$ level and stomatal conductance was maximum at the range of 1.00 to 1.5 $\mathrm{mL} \cdot \mathrm{L}^{-1}$ thus predicting the stimulatory effect of phenolics at lower concentration [26]. It is the major debate of today that decreased photosynthesis under stress is the result of stomatal as well as inhibition of primary photochemical and biochemical processes. [27] [28]. Water stress damage oxygen evolving complex of photosysten II and its reaction centers [29].

The relative membrane permeability increases with increase in stress [30] that coincide with the result of experiment for the dilution range from 1.00 to 1.50 $\mathrm{mL} \cdot \mathrm{L}^{-1}$ Sorgaab on stressed plants. Anthocyanins increases in drought stressed Cucumis sativus [31] and Quercus spp. [32]. Plants utilize foliar anthocyanins to reduce evapotranspiration. The stressed plants produced maximum anthocyanins at 0.25 to $0.75 \mathrm{~mL} \cdot \mathrm{L}^{-1}$ Sorgaab spray indicating that these concentrations are less effective in overcoming the drought effect.

In nature, plants have its own defense system against environmental stresses by producing antioxidants that scavenge the reactive oxygen species [33]. Various antioxidants were analyzed in respective experiment to examine the effect of drought and Sorgaab. Total free amino acids were found to be two fold higher in drought as compared to control and it increases with increase in concentration of foliar spray of Sorgaab ranging from 1.00 to $2.00 \mathrm{~mL} \cdot \mathrm{L}^{-1}$ highest at 1.75 $\mathrm{mL} \cdot \mathrm{L}^{-1}$. The increase in free amino acids could contribute to the tolerance of plant to water deficit through an increase in osmotic potential [34]. This higher level may be the result of diminished synthesis of protein or increase in its breakdown. An increased level of amino acids was reported in sorghum plants from moderate to severe stress [35]. Other oxidants such as $\mathrm{H}_{2} \mathrm{O}_{2}$, and soluble phenolic were found to be greater in drought conditions as compared to control their concentrations were higher at higher Sorgaab dilutions from 1.00 to 2.00 $\mathrm{mL} \cdot \mathrm{L}^{-1}$. The contents of MDA were lower in stressed plants treated with 0.25 to $1.5 \mathrm{~mL} \cdot \mathrm{L}^{-1}$ Sorgaab as compared to unsprayed water or high dilutions of Sorgaab (1.75 and $2.00 \mathrm{~mL} \cdot \mathrm{L}^{-1}$ ) (Figure 4) as reported by [36] that triazole-a growth regulator treated Echinochloa frumentacea showed better growth and lower MDA, a by-product of lipid peroxidation due to increased activity of endogenous $\mathrm{H}_{2} \mathrm{O}_{2}$ scavenging system.

Roots are the part of plants that first come in direct contact with allelochemicals as most of them are released in the soil [37]. They effect the growth of plants by inhibiting the ions uptake, mainly due to membrane perturbation [38]. The reduced nitrate uptake in maize seedlings at higher concentration of $p$-coumaric, ferulic acid and trans-cinnamic acid, however lower concentration of caffeic acid enhanced nitrate uptake [39]. The present study also revealed that at dilutions of 
0.75 to $1.75 \mathrm{~mL} \cdot \mathrm{L}^{-1}$ Sorgaab, greater $\mathrm{NO}_{3}, \mathrm{PO}_{4}, \mathrm{Ca}^{2+}, \mathrm{K}^{+}$uptake as compared to higher concentrations. There are many other reports [38] indicated the greater inhibition of ion uptake by phenolic acids (cinnamic acid, benzoic acid).

\section{Conclusion}

In conclusion, foliar application of diluted concentrations of Sorgaab can be utilized as a natural source for improving drought resistance in maize.

\section{References}

[1] Merkl, R., Hradkova, I., Filip, V. and Smidrka, J. (2010) Antimicrobial and Antioxidant Properties of Phenolic Acids Alkyl Esters. Czech Journal of Food Science, 28, 275-279.

[2] Lattanzio, V., Lattanzio, V.M.T. and Cardinali, A. (2006) Role of Phenolics in the Resistance Mechanism of Plants against Fungal Pathogen and Insects. Phytochemistry. Advance Research, 23-67.

[3] Olofsdotter, M., Rebulanan, M., Madrid, A., Dali, W., Navarez, D. and Olk, D.C. (2002) Why Phenolics Acids Are Unlikely Primary Allelochemicals in Rice. Journal of Chemical Ecology, 28, 229-242. https://doi.org/10.1023/A:1013531306670

[4] Guenzi, W.D., McCalla, I.M. and Norstad, F.A. (1967) Presence and Persistence of Phytotoxic Substancedd in Wheat, Oat, Corn and Sorghum Residues. Agronomy Journal, 59, 163-165. https://doi.org/10.2134/agronj1967.00021962005900020012x

[5] Einhellig, F.A. and Rasmussen, J.A. (1978) Synergistic Inhibitory Effects of Vanillic and p-Hydrozbenzoic Cids on Radish and Grain Sorghum. Journal of Chemical Ecology, 4, 425-436. https://doi.org/10.1007/BF00989499

[6] Cheema, Z.A. (1988) Weed Control in Wheat through Sorghum Allelochemicals. PhD Thesis, Department Agronomy, University of Agriculture, Faisalabad.

[7] Cheema, Z.A., Luqman, M. and Khaliq, A. (1997) Use of Allelopathic Extracts of Sorghum and Sunflower Herbage for Weed Control in Wheat. Journal of Animal Plant Science, 7, 91-93.

[8] Khaliq, A., Iqbal, M. and Basra, S.M.A. (1999) Optimization of Seeding Density and Nitrogen Application in Wheat cv. Inqalab-91 under Faisalabad Condition. International Journal of Agriculture and Biology, 1, 241-243.

[9] Iqbal, J. and Cheema, Z.A. (2008) Purple Nutsedge (Cyperus rotundus L.) Management in Cotton with Combined Application of Sorgaab and s-Metolachlor. Pakistan Journal of Botany, 40, 2383-2391.

[10] Rice, E.L. (1984) Allelopathy. Academic Press, New York.

[11] Wahid, A. and Ghazanfar, A. (2006) Possible Involvement of Some Secondary Metabolites in Salt Tolerance of Sugarcane. Journal of Plant Physiology, 163, 723-730.

[12] Wahid, A. (2007) Physiological Implications of Metabolite Biosynthesis for Net Assimilation and Heat Stress Tolerance of Sugarcane (Saccharum officinarum) Sprouts. Journal of Plant Research, 120, 219-228. https://doi.org/10.1007/s10265-006-0040-5

[13] Anonymous (2005) Pakistan Statistical Yearbook. MINFAL, Government of Pakistan, Islamabad.

[14] Farooq, M., Wahid, A., Kobayashi, N., Fujita, D. and Basra, S.M.A. (2009) Plant Drought Stress: Effects, Mechanisms and Management. Agronomy Sustainable Development, 29, 185-212. https://doi.org/10.1051/agro:2008021

[15] Khalid, S., Ahmad, T. and Shad, R.A. (2002) Use of Allelopathy in Agriculture. 
Asian Journal of Plant Science, 1, 292-297.

https://doi.org/10.3923/ajps.2002.292.297

[16] Singh, H.P., Batish, D.R. and Kohli, R.K. (2003) Allelopathic Interactions and Allelochemicals: New Possibilities for Sustainable Weed Management. Critical Reviews in Plant Science, 22, 239-311. https://doi.org/10.1080/713610858

[17] Javaid, A., Shafique, S., Bajwa, R. and Shafique, S. (2006) Effect of Aqueous Extracts of Allelopathic Crops on Germination and Growth of Parthenium hysterophorus $\mathrm{L}$. South African Journal of Botany, 72, 609-612.

[18] Batish, D.R., Lavanya, K., Singh, H.P. and Kohli, R.K. (2007) Phenolic Allelochemicals Released by Chenopodium murale Affect the Growth, Nodulation and Macromolecule Content in Chickpea and Pea. Plant Growth Regulation, 51, 119-128. https://doi.org/10.1007/s10725-006-9153-Z

[19] Ambika, S.R. and Poornima, S. (2006) Allelochemicals from Chromolaena odorata (L.) King and Robinson for Increasing Crop Productivity. Allelopathy Journal, 18, 2.

[20] Fujii, Y. (2003) Allelopathy in the Natural and Agricultural Ecosystems and Isolation of Potent Allelochemicals from Velvet Bean (Mucuna pruriens) and Hairy Vetch (Vicia villosa). Biological Science Space, 17, 6-13. https://doi.org/10.2187/bss.17.6

[21] Taiz, L. and Zeiger, E. (2010) Plant Physiology. 5th Edition, Sinauer Associates, Sunderland.

[22] Zavalloni, C., Gielen, B., de Boeck, H.J., Lemmens, C.M., Ceulemans, R. and Nijs, I. (2009) Greater Impact of Extreme Drought on Photosynthesis of Grassland Exposed to Warmer Climate in Spite of Acclimation. Plant Physiology, 136, 57-72. https://doi.org/10.1111/j.1399-3054.2009.01214.x

[23] Dubey, R.S. (2005) Photosynthesis in Plants under Stress Full Conditions. In: Pessarakli, M., Ed., Photosynthesis, CRC Press, New York, 717-718.

[24] Cornic, G. (1994) Drought Stress and High Light Effects on Leaf Photosynthesis. In: Baker, N.R. and Boyer, J.R., Eds., Photoinhibition of Photosynthesis. From Molecular Mechanisms to the Field, Bios Scientific Publishers, Oxford, 297-313.

[25] Cornic, G., Ghashghaie, Genty, B. and Briantais, J.-M. (1992) Leaf Photosynthesis Is Resistant to a Mild Drought Stress. Photosynthetica, 27, 295-300.

[26] Uddin, M.B., Ahmed, R., Mukul, S.A. and Hossain, M.K. (2007) Inhibitory Effects of Albizia lebbeck Leaf Extracts on Germination and Growth Behavior of Some Popular Agricultural Crops. Journal of Forestry Research, 18, 128-132. https://doi.org/10.1007/s11676-007-0025-9

[27] Lawlor, D.W. (2002) Limitation of Photosynthesis in Water-Stressed Leaves. Stomatal Metabolism and the Role of ATP. Annals of Botany, 89, 871-885. https://doi.org/10.1093/aob/mcf110

[28] Lauer, K.J. and Boyer, J.S. (1992) Internal CO2 Measures Directly in Leaves: Abscisic Acid a Low Leaf Water Potential Cause Opposing Effects. Plant Physiology, 98, 1010-1016. https://doi.org/10.1104/pp.98.4.1310

[29] Terzi, R., Saglam, A., Kutlu, N., Nar, H. and Kadioglu, A. (2010) Impact of Soil Drought Stress on Photochemical Efficiency of Photosystem II and Antioxidant Enzyme Activities of Phaseolus vulgaris Cultivars. Turkey Journal of Botany, 34, 110.

[30] Liu, Y., Cao, T. and Glime, J.M. (2003) The Changes of Membrane Permeability of Mosses under High Temperature Stress. The Bryologist, 106, 53-60. https://doi.org/10.1639/0007-2745(2003)106[0053:TCOMPO]2.0.CO;2 
[31] Zhi-Min, Y., Shao-Jian, Z., Ai-Tong, H., You-Fei, Z. and Jing-Yi, Y. (2000) Response of Cucumber Plants to Increased UV-B Radiation under Water Stress. Journal of Environmental Science, 12, 236-240.

[32] Spyropoulos, C.G. and Mavrommatis, M. (1978) Effect of Water Stress on Pigment Formation in Quercus Species. Journal of Experimental Botany, 29, 473-477. https://doi.org/10.1093/jxb/29.2.473

[33] Arora, A., Sairam, R.K. and Srivastava, G.C. (2002) Oxidative Stress and Antioxidative Systems in Plants. Current Science, 82, 1227-1238.

[34] Navari-Izzo, F., Quartacci, M.F. and Izzo, M.F. (1990) Water Stress Induce Changes in Protein an Fress Amino Acids in Field-Grown Maize and Sunflower. Plant Physiology and Biochemistry, 28, 531-537.

[35] Jones, M.M., Osmond, C.B. and Turner, N.C. (1980) Accumulation of Solutes in Leaves of Sorghum and Sunflower in Response to Water Deficit. Australian Journal of Plant Physiology, 7, 193-205. https://doi.org/10.1071/PP9800193

[36] Sankhla, N., Upadhyaya, A., Davis, T.D. and Sankhla, D. (1992) Hydrogen Peroxide-Scavenging Enzymes and Antioxidants in Echinocloa frumentacea as Affected by Triazole Growth Regulators. Plant Growth Regulation, 11, 1573-5087. https://doi.org/10.1007/BF00130654

[37] Whitehead, D.C. (1964) Identification of p-Hydroxybenzoic, Vanillic, p-Coumaric, and Ferulic Acids in Soils. Nature, 202, 417-418. https://doi.org/10.1038/202417a0

[38] Yu, J.Q. and Matsui, Y. (1997) Effects of Root Exudates of Cucumber (Cucumis sativus) and Allelochemicals on Ions Uptake by Cucumber Seedlings. Journal of Chemical Ecology, 23, 817 827. https://doi.org/10.1023/B:JOEC.0000006413.98507.55

[39] Abenavoli, M.R., Lupini, A., Oliva, S. and Sorgona, A. (2010) Allelochemicals Effects on Net Nitrate Uptake and Plasma Membrane H+-ATPase Activity Ion Maize Seedlings. Biologia Plantarum, 54, 149-153.

https://doi.org/10.1007/s10535-010-0024-0

\section{Submit or recommend next manuscript to SCIRP and we will provide best} service for you:

Accepting pre-submission inquiries through Email, Facebook, LinkedIn, Twitter, etc. A wide selection of journals (inclusive of 9 subjects, more than 200 journals)

Providing 24-hour high-quality service

User-friendly online submission system

Fair and swift peer-review system

Efficient typesetting and proofreading procedure

Display of the result of downloads and visits, as well as the number of cited articles

Maximum dissemination of your research work

Submit your manuscript at: http://papersubmission.scirp.org/

Or contact ajps@scirp.org 